\title{
KARAKTERISTIK GELATIN DARI KULIT KAKI TERNAK DAN POTENSINYA SEBAGAI EDIBLE FILM
}

\author{
MIWADA, IN.S. ${ }^{1)}$ DAN I N. SIMPEN ${ }^{2)}$, M. HARTAWAN ${ }^{1)}$, \\ A. W. PUGER ${ }^{1)}$, DAN N. L. P. SRIYANI ${ }^{1)}$ \\ 1) Fakultas Peternakan Universitas Udayana \\ 2) Jurusan Kimia, FMIPA Universitas Udayana \\ e-mail : nymsumerta@yahoo.co.id
}

\begin{abstract}
ABSTRAK
Tujuan penelitian ini adalah mengembangkan potensi protein kolagen yang terdapat pada kulit kaki ternak (kulit kaki ayam broiler/kka, kulit kaki kambing/kkk dan kulit kaki sapi/kks) menjadi produk gelatin dan mengkaji potensinya sebagai edible film. Ekstraksi protein pada kka, kks, dan kkk dalam water bath yang sebelumnya dicuring dengan asam asetat $(1,5 \%)$ selama 3 hari. Dilanjutkan produksi edible film dalam 100 ml aquades dengan perlakuan formulasi gelatin dan gliserol (1:0); (5:1); (10:1); (15:1) dan (20:1). Hasil penelitian menunjukkan bahwa gelatin kks paling tinggi $(\mathrm{P}<0,05)$ kandungan proteinnya $(85,17 \%)$ diikuti gelatin kkk $(80,38 \%)$ dan kka $(79,43 \%)$. Namun secara viskositas gelatin kkk (5,70 poise) paling tinggi $(\mathrm{P}<0,05)$ diikuti oleh kks $(5,27$ poise) dan kka $(4,93$ poise). Hasil analisis FTIR menunjukkan bahwa gelatin jenis kks, kkk, dan kka terbukti sebagai gelatin melalui karakterisasi serapan gugus fungsi. Karakterisasi tersebut terbagi dalam 4 bagian puncak serapan khas gelatin yaitu serapan amida A, amida I, amida II dan amida III. Kajian penggunaan jenis gelatin-gliserol dengan rasio berbeda menghasilkan viskositas edible film yang cenderung meningkat $(\mathrm{P}<0,05)$ dengan rentang rata-rata 1,893,77 poise. Sementara kandungan proteinnya nyata berbeda dengan nilai tertinggi pada rasio 10:1. Kandungan protein edible dari gelatin kkk tertinggi $(\mathrm{P}<0,05)$ diikuti kka dan kks dengan nilai berturut-turut $(0,38 \% ; 0,27 \%$ dan $0,25 \%)$. Kesimpulan penelitian bahwa gelatin kks nilainya lebih tinggi diikuti kkk dan kka. Penggunaan ketiga jenis gelatin ini sebagai edible film menghasilkan formula terbaik pada rasio 10:1 yaitu 10 g gelatin dan $1 \mathrm{ml}$ gliserol dalam $100 \mathrm{ml}$ aquades.
\end{abstract}

Kata kunci: kulit kaki ternak, ekstraksi, gelatin, edible film

\section{CHARACTERISTICS GELATIN OF SKIN FOOT ANIMALS AND POTENTIAL AS EDIBLE FILMS}

\begin{abstract}
The purpose of this research is to develop the potential of the protein collagen in the skin of foot animals (foot skin of broiler / $k k a$, foot skin of goat / $k k k$ and foot skin of cow / $k k s$ ) into gelatin products and assess its potential as an edible film. Extraction of proteins on $k k a, k k s$, and $k k k$ in a water bath previously cured with acetic acid (1.5\%) for 3 days. Continued production of edible film in $100 \mathrm{ml}$ of distilled water with gelatin and glycerol treatment formulations $(1: 0) ;(5: 1) ;(10: 1) ;(15: 1)$ and $(20: 1)$. The results showed that the gelatin $k k s$ highest $(\mathrm{P}<0.05)$ protein content $(85.17 \%)$ followed by gelatin $k k k(80.38 \%)$ and $k k a(79.43 \%)$. But the $k k k$ gelatin viscosity (5.70 poise) the highest $(\mathrm{P}<0.05)$ followed by the kks (5.27 poise) and $k k a$ (4.93 poise). Results of FTIR analysis showed that the gelatin type $k k s, k k k$, and $k k a$ proved as gelatin through absorption characterization of functional groups. Characterization is divided into 4 sections namely gelatin typical absorption peak absorption amide A, amide I, amide II and amide III. Study of the use of types of gelatin-glycerol with different ratios that produce edible film viscosity tended to increase $(\mathrm{P}<0.05)$ with the average range from 1.89 to 3.77 poise. While the protein content significantly different with the highest value at a ratio of 10:1. Protein content of edible gelatin $k k k$ highest $(\mathrm{P}<0.05)$ followed by $k k a$ and $k k s$ with values (0.38\%, $0.27 \%$ and $0.25 \%)$, respectively. Research conclusion that gelatin is higher $k k s$ followed $k k k$ and $k k a$. The use of these three types of gelatin as an edible film produces the best formula on the ratio of 10:1 is 10 grams of gelatin and $1 \mathrm{ml}$ of glycerol in $100 \mathrm{ml}$ of distilled water.
\end{abstract}

Keywords: skin foot cattle, extraction, gelatin, edible film 


\section{PENDAHULUAN}

Kulit kaki ternak adalah salah satu limbah (by product) yang ditemukan di tempat pemotongan hewan yang jumlahnya berlimpah dan keberadaannya menyatu dengan komponen lainnya, yakni tulang kaki ternak. Kandungan protein kolagen pada kulit kaki yang tinggi, yakni lebih dari 80\% (Purnomo, 1992) merupakan potensi ekonomi yang belum maksimal dimanfaatkan. Potensi kulit kaki ternak sebagai bahan baku edible film perlu dikaji untuk memberi sentuhan nilai guna (added value) yang lebih tinggi dari by product ini. Edible film merupakan kemasan yang bersifat biodegradable yang ramah lingkungan dan mudah diuraikan. Kajian penelitian pencarian sumber-sumber bahan baku kemasan yang bersifat biodegradable perlu dilakukan, mengingat potensi kemasan ini kedepan semakin tinggi sebagai alternatif dari kemasan yang sintetis dan menjanjikan. Menurut definisinya, edible film merupakan lapisan tipis yang dapat dimakan, dibentuk melapisi komponen makanan (coating), ditempatkan di atas atau di antara komponen makanan. Dalam produk pangan, lapisan tipis ini berfungsi untuk penghambat perpindahan uap air (Krochta et al ., 1994) dan pertukaran gas (Liu dan Han, 2005), mencegah kehilangan aroma dan perpindahan lemak (Krochta dan Johnson, 1997), meningkatkan karakteristik fisik, dan sebagai pembawa zat aditif serta bersifat ramah lingkungan (Kim dan Ustunol, 2001) dan (Simelane dan Ustunol, 2005). Menurut Donhowe dan Fennema (1993) bahwa bahan dasar pembentuk edible film dapat terdiri hidrokoloid, lipida, dan komposit. Hidrokoloid yang cocok antara lain senyawa protein, turunan selulosa, alginat, pektin, pati dan polisakarida lainnya (Caner et al., 1998). Lipida yang biasa digunakan waxes, asilgliserol, dan asam lemak. Sedangkan, komposit merupakan gabungan lipida dengan hidrokoloid.

Selama ini bahan baku edible film yang banyak digunakan adalah dari golongan pati, sedangkan golongan protein dari ternak masih jarang digunakan. Salah satu bahan baku edible film dari golongan protein asal ternak yang memiliki sifat-sifat yang baik dan diduga berpotensi untuk digunakan sebagai bahan baku adalah protein pada kulit kaki ternak. Pemanfaatan kulit kaki ternak ini sebagai bahan baku edible film perlu dilakukan dengan terlebih dahulu dilakukan proses gelatinisasi pada protein kolagen yang ditemukan pada kulit kaki ternak. Proses gelatinisasi protein kolagen pada kulit kaki ternak dapat dilakukan dengan metode modifikasi dari Miwada dan Simpen (2005). Kajian potensi protein kolagen pada kulit kaki ternak meliputi kulit kaki ayam, kulit kaki kambing dan kulit kaki sapi. Potensi dari ketiga jenis bahan baku yang berbeda ini diduga akan memberikan karakteristik yang berbeda pada edible film. Tujuan penelitian ini adalah mengevaluasi hasil ekstraksi protein kolagen pada kulit kaki ayam (kka); kulit kaki sapi (kks); dan kulit kaki kambing (kkk) sebagai bahan baku gelatin dan aplikasinya sebagai edible film.

\section{MATERI DAN METODE}

\section{Materi}

Materi utama penelitian adalah kulit kaki ayam (kka) yang dibeli rumah potong ayam di Denpasar; kulit kaki sapi (kks) dan kulit kaki kambing (kkk) yang dibeli dari Tulung Agung, Jawa Timur. Bahan kimia yang digunakan meliputi aquades, asam asetat (1,5\%), alkohol 70\%, etanol dan gliserol. Peralatan yang digunakan meliputi: toples ukuran $10 \mathrm{~L}$ (3 buah), gelas ukur $1 \mathrm{~L}$, pipet, tang, pisau, piring/wadah, talanan, baskom, gunting, lap, timbangan manual, ember plastik, panci aluminium, toples tempat sampel ukuran $250 \mathrm{~mL}$, saringan kasa, tray, kasa, pinset, botol film tempat sampel kering, aluminium foil, masker, plastik, dan kertas saring. botol untuk ekstraksi ukuran 500 $\mathrm{mL}$, gelas ukur $100 \mathrm{~mL}$, pipet ukur, pipet volume, labu ukur, gelas beaker, dan Erlenmeyer, neraca, hot plate, penangas air, corong, termometer, cawan petri, batang pengaduk spatula, desikator, oven, dan oven.

\section{Metode}

Tahap pelaksanaan penelitian, dimulai dengan pembuatan larutan asam asetat dengan konsentrasi 1,5\%. Selanjutnya , kulit ceker ayam, kulit kaki kambing dan kulit kaki sapi yang telah disiapkan dengan metode pengulitan konvensional, selanjutnya diberi perlakuan curing dengan asam asetat dengan perbandingan (1:8). Curing dilakukan selama 3 hari, dilanjutkan dengan minimalisasi kandungan lemak dengan menggunakan larutan etanol 65\% (rasio gelatin : etanol yakni 1:2) dengan perendaman dalam 1 jam. Hasil minimalisasi lemak, dilanjutkan dengan ekstraksi dengan penambahan aquades (rasio 1:1) dan dilakukan dalam water bath dengan suhu $61^{\circ} \mathrm{C}-65^{\circ} \mathrm{C}$ selama 1 jam, dilanjutkan dengan pencucian, penyaringan, penguapan larutan pengekstrak, dan pengentalan produk gelatin yang diperoleh. Uji karakteristik gelatin dari bahan baku kulit yang berbeda diuji melalui pendekatan FTIR untuk mengetahui gugus fungsi gelatin yang ada, kandungan protein, dan viskositasnya.

Dilanjutkan dengan melakukan formulasi semua potensi gelatin dari jenis bahan baku yang berbeda tersebut untuk dijadikan edible film. Formulasi ekstrasi jenis gelatin dari masing-masing perlakuan kka, kkk, dan kks (tahap pertama) dengan bahan pemelastik (plasticizer) jenis gliserol dengan rasio (1:0); (5:1) (5 bagian gelatin dan 1 bagian gliserol); 
(10:1); (15:1) dan (20:1). Setiap kombinasi perlakuan yang diterapkan dilakukan pengulangan sebanyak 3 kali. Proses pembuatan edible film dilakukan secara casting menurut metode Carvalho et al. (2007) dan Sobral (2001) dengan sedikit modifikasi. Larutan film yang telah dibuat, selanjutnya dimasukkan ke dalam water bath dan dipanaskan pada suhu $700 \mathrm{C}$ selama 45 menit sambil diaduk hingga partikel gelatin dan gliserol tercampur secara sempurna (homogen). Larutan kemudian dituang pada wadah cetakan teflon setipis mungkin dalam keadaan panas dan selanjutnya ditempatkan pada oven dalam posisi rata. Teflon yang berisi larutan film kemudian dikeringkan pada suhu 550C selama 18-20 jam hingga terbentuk lapisan tipis. Teflon kemudian dikeluarkan dari oven dan dikondisikan dengan suhu ruangan selama kurang lebih 10 menit. Secara perlahan-lahan lapisan tipis yang terbentuk dikelupas (peeling) dengan ujung pisau yang tumpul hingga keseluruhan lapisan film terlepas. Film kemudian dibungkus dengan plastik bening dan dimasukkan ke dalam wadah plastik yang sebelumnya diberi dengan silika gel untuk mencegah kerusakan film oleh kelembaban dan selanjutnya film siap untuk diuji. Produk edible yang telah dihasilkan diuji kimia (kandungan protein) dan uji fisik (viskositas).

Desain penelitian tahap pertama dilaksanakan secara eksperimental berdasarkan rancangan acak lengkap (RAL) pola sederhana dengan 3 jenis perlakuan (bahan baku gelatin dari kulit kaki ayam broiler (kka); kulit kaki kambing (kkk) dan kulit kaki sapi (kks)). Sementara penelitian tahap kedua, dilaksanakan secara eksperimental berdasarkan Rancangan Acak Lengkap (RAL) pola Faktorial $3 \mathrm{X}_{5}$ dengan ulangan 3 kali. Perlakuan yang diterapkan yakni faktor I terdiri atas 3 jenis bahan baku gelatin (kka; kkk; dan kks) (b/v) dan faktor II terdiri atas 5 ratio gelatin dan gliserol (dengan penekanan tetap berbasis dominan gelatin) yakni (1:0); (5: 1); (10:1); (15:1) dan (20:1). Data yang diperoleh dianalisis secara sidik ragam dengan bantuan program statistik SPSS Versi 16,o. Perlakuan yang menunjukkan pengaruh yang nyata, selanjutnya dilakukan uji beda nyata dengan Duncan's Multiple Range Test (DMRT) pada taraf 5\% (Steel dan Torrie, 1991).

\section{HASIL DAN PEMBAHASAN}

Hasil ekstraksi protein kolagen pada kulit kaki ayam, kulit kaki sapi dan kulit kaki kambing secara lengkap disajikan pada Tabel 1 berikut.

Hasil penelitian tahap pertama ini (Tabel 1), terjadi peningkatan volume pada masing-masing sampel akibat mengembangnya protein kolagen pada kulit oleh perlakuan asam asetat. Berat pasca curing tertinggi diperoleh pada perlakuan curing kulit kaki ayam,
Tabel 1. Berat Kulit dan Volume Gelatin yang Dihasilkan

\begin{tabular}{lcccc}
\hline \multicolumn{1}{c}{ Jenis Kulit } & Berat (gr) & $\begin{array}{c}\text { Volume asam } \\
\text { asetat (L) }\end{array}$ & $\begin{array}{c}\text { Berat Pasca } \\
\text { Curing (gr) }\end{array}$ & $\begin{array}{c}\text { Volume } \\
\text { Gelatin }(\mathrm{mL})\end{array}$ \\
\hline Kaki ayam broiler & 1000 & 8 & 3650 & 5850 \\
Kaki sapi & 1000 & 8 & 2000 & 2066 \\
Kaki kambing & 1000 & 8 & 1900 & 1875 \\
\hline
\end{tabular}

diikuti kulit kaki sapi dan terendah kaki kambing. Demikian pula pada volume gelatin yang dihasilkan, volume gelatin kaki ayam paling tinggi, diikuti kaki sapi dan kaki kambing. Volume gelatin yang diperoleh dari masing-masing perlakuan diuji kebenaran gugus fungsi gelatin melalui pendekatan FTIR.

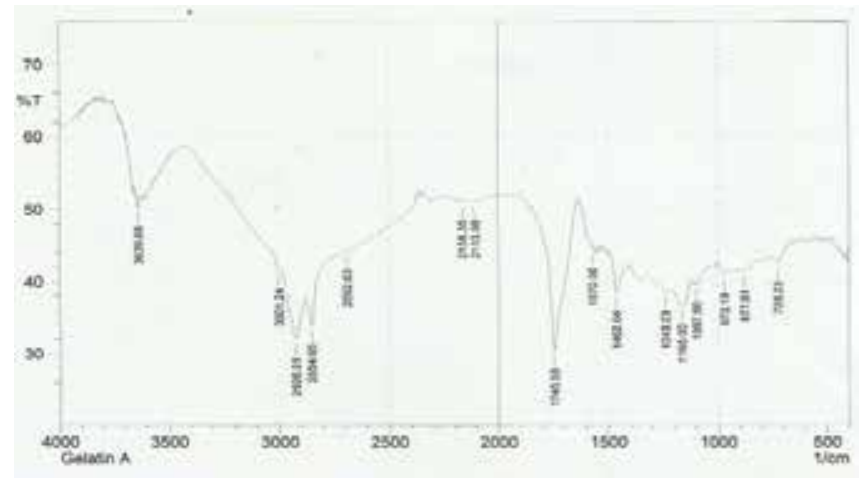

Gambar 1. Hasil analisa FTIR gelatin dari ekstrak protein kulit kaki ayam

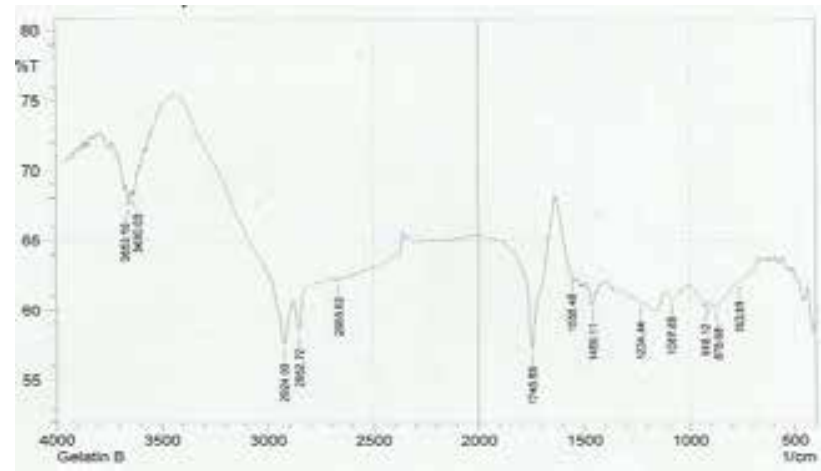

Gambar 2. Hasil analisa FTIR gelatin dari ekstrak protein kulit kaki sapi

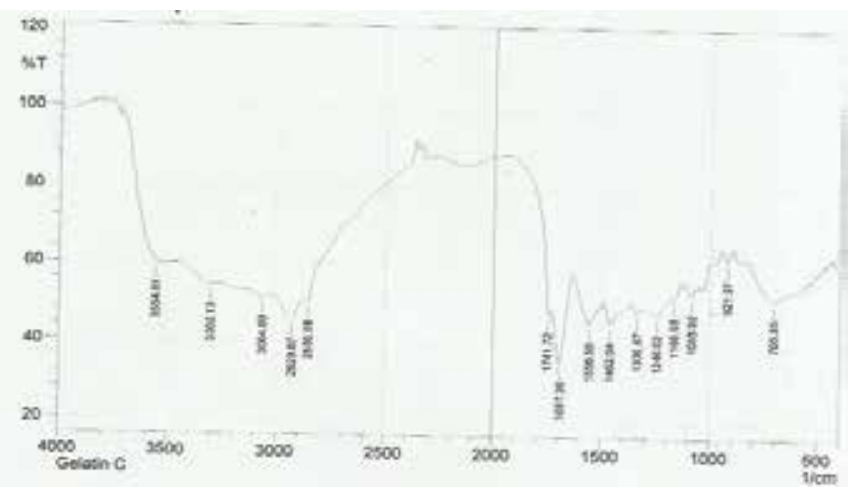

Gambar 3. Hasil analisa FTIR gelatin dari ekstrak protein kulit kaki kambing 
Tabel 2. Karakteristik kimia fisik gelatin kulit kaki ayam, kulit kaki sapi dan kulit kaki kambing

\begin{tabular}{cccc}
\hline \multirow{2}{*}{ Variabel } & \multicolumn{3}{c}{ Perlakukan } \\
\cline { 2 - 4 } & $\begin{array}{c}\text { Kulit kaki ayam } \\
(\text { kka) }\end{array}$ & Kulit kaki sapi (kks) & $\begin{array}{c}\text { Kulit kaki kambing } \\
(\text { kkk) }\end{array}$ \\
\hline Kadar protein (\%) & $79,43 \pm 0,46^{\text {a }}$ & $85,17 \pm 0,21^{\mathrm{b}}$ & $80,38 \pm 0,70^{\mathrm{a}}$ \\
Viskositas (poise) & $4,93 \pm 0,10^{\mathrm{a}}$ & $5,27 \pm 0,18^{\mathrm{b}}$ & $5,70 \pm 0,13^{\mathrm{c}}$ \\
\hline
\end{tabular}

\section{Keterangan :}

Huruf yang berbeda pada baris yang sama menunjukkan adanya perbedaan yang nyata $(P<0,05)$ berdasarkan uji Duncan

Hasil spectra FTIR seperti pada gambar diatas menunjukkan bahwa gugus-gugus fungsi dari gelatin yang meliputi $\mathrm{O}-\mathrm{H}, \mathrm{C}-\mathrm{H}, \mathrm{C}=\mathrm{O}, \mathrm{N}-\mathrm{H}$ dan $\mathrm{C}-\mathrm{H}$ aromatis teridentifikasi pada ketiga produk gelatin diatas. Hal ini menjadi bukti bahwa produk yang dihasilkan pada penelitian ini betul-betul gelatin. Hal itu sesuai dengan pendapat Puspawati et al. (2011) yang menyebutkan bahwa gelatin seperti halnya protein pada umumnya strukturnya tersusun dari carbon, hidrogen, gugus hidroksil, gugus carbonil dan gugus amina. Selanjutnya pengujian dilakukan meliputi uji fisik dan kimia. Ratarata hasil pengujian secara lengkap disajikan pada tabel 2 berikut.

Secara statistik, hasil pengamatan pada Tabel 2, menunjukkan bahwa gelatin dari bahan baku kulit kaki sapi tertinggi kadungan proteinnya, diikuti oleh gelatin dari kaki kambing dan kulit kaki ayam $(\mathrm{P}<0,05)$ Sementara secara fisik, khususnya dari variabel viskositas ternyata gelatin dari kulit kaki kambing yang tertinggi, diikuti gelatin dari kulit kaki sapi dan ayam. Hasil kajian penelitian ini sesuai dengan pendapat Sarkar (1995) yang menyebutkan bahwa gelatin sebagai produk hasil hidrolisis protein kolagen kulit ditentukan oleh kandungan protein kolagen pada kulit segarnya. Lebih lanjut disebutkan bahwa kandungan kolagen pada kulit sapi dewasa cukup tinggi $(87,2 \% \mathrm{bk})$. Namun dari hasil penelitian ini diduga tidak selalu positif dengan semakin tingginya kandungan protein kolagen kulit dengan tingkat viskositas gelatin yang dihasilkan. Hal ini sesuai dengan hasil penelitian pada Tabel 2, tingginya kandungan protein pada gelatin dari kks tidak diikuti dengan viskositas yang tinggi, malah justru viskositas gelatin dari kkk yang paling tinggi.

Karakteristik gelatin hasil hidrolisis protein kolagen dari masing-masing jenis kulit kaki ayam broiler, kulit kaki sapi dan kulit kaki kambing selanjutnya dijadikan bahan baku dalam pembuatan edible film. Edible film berbasis gelatin yang sebelumnya diinteraksikan dengan gliserol. Edible film dibuat dengan rancang penggunaan gelatin dengan variasi yang berbeda dan gliserol dengan kuantitas tetap (Tabel 3). Rasio gelatin : gliserol yang dirancang meliputi (1:0); (5:1); (10:1); (15:1) dan (20:1). Dilanjutkan proses pemanasan dalam water bath pada suhu $60-70^{\circ} \mathrm{C}$ selama 15 menit sambil diaduk merata. Pengujian sampel edible film dalam kondisi cair karena dalam aplikasinya sebagai edible coating.

Tabel 3 menunjukkan bahwa dalam pembuatan edible film ini penekanannya pada penggunaan gelatin

Tabel 3. Jumlah (gr) penggunaan gelatin sebagai bahan baku edible film (rasio gelatin : gliserol ) berbeda

\begin{tabular}{cccccc}
\hline Perbandiangan & Gelatin Ayam $(\mathrm{gr})$ & Gelatin Sapi $(\mathrm{gr})$ & Gelatin Kambing $(\mathrm{gr})$ & Gliserol $(\mathrm{mL})$ & Aquades $(\mathrm{mL})$ \\
\hline $1: 0$ & 1,0473 & 1,04351 & 1,0391 & 0 & 1 \\
$1: 1$ & 5,0093 & 5,0178 & 5,0083 & 1 & 100 \\
$10: 1$ & 10,0271 & 10,0081 & 10,0073 & 1 & 100 \\
$15: 1$ & 15,0417 & 15,0322 & 15,0418 & 1 & 100 \\
$20: 1$ & 20,0081 & 20,0518 & 20,0511 & 100 \\
\hline
\end{tabular}

Tabel 4. Viskositas (poise) edible film berbasis gelatin dari aneka kulit kaki ternak

\begin{tabular}{lcccccc}
\hline Jenis Bahan Baku & \multicolumn{5}{c}{ Rasio Gelatin dan Gliserol } \\
\cline { 2 - 6 } \multicolumn{1}{c}{ Edible } & $1: 0$ & $5: 1$ & $10: 1$ & $15: 1$ & $20: 1$ & Rataan \\
\hline Gelatin kka & 2,00 & 2,30 & 3,77 & 3,18 & 2,08 & $2,67 \pm 0,72^{\mathrm{a}}$ \\
Gelatin kks & 1,89 & 2,03 & 2,87 & 2,43 & 2,31 & $2,31 \pm 0,38^{\mathrm{b}}$ \\
Gelatin kkk & 2,01 & 2,04 & 2,71 & 2,69 & 2,59 & $2,41 \pm 0,33^{\mathrm{c}}$ \\
Rataan & $1,97 \pm 0,10^{\mathrm{a}}$ & $2,12 \pm 0,14^{\mathrm{b}}$ & $3,12 \pm 0,50^{\mathrm{c}}$ & $2,77 \pm 0,36^{\mathrm{d}}$ & $2,3 \pm 0,26^{\mathrm{e}}$ & \\
\hline
\end{tabular}

Tabel 5. Protein (\%) edible film berbasis gelatin dari aneka kulit kaki ternak

\begin{tabular}{ccccccc}
\hline Jenis Bahan Baku & \multicolumn{5}{c}{ Rasio Gelatin dan Gliserol } \\
\cline { 2 - 6 } Edible & $1: 0$ & $5: 1$ & $10: 1$ & $15: 1$ & $20: 1$ & 0,28 \\
Gelatin kka & 0,28 & 0,24 & 0,27 & 0,27 & $0,27 \pm 0,02^{\mathrm{a}}$ \\
Gelatin kks & 0,29 & 0,28 & 0,27 & 0,29 & 0,25 & $0,28 \pm 0,02^{\mathrm{a}}$ \\
Gelatin kkk & 0,34 & 0,32 & 0,30 & 0,35 & 0,48 & $0,36 \pm 0,07^{\mathrm{b}}$ \\
Rataan & $0,30 \pm 0,04^{\mathrm{a}}$ & $0,28 \pm 0,04^{\mathrm{b}}$ & $0,28 \pm 0,02^{\mathrm{b}}$ & $0,30 \pm 0,04^{\mathrm{a}}$ & $0,34 \pm 0,11 \mathrm{c}$ & \\
\hline
\end{tabular}


sebagai bahan dasar utamanya dengan penggunaan gliserol sebagai fungsi pelemas edible dengan porsi yang sama pada seluruh kombinasi perlakuan (gelatin dan gliserol). Formula edibel coating yang dihasilkan dari seluruh kombinasi perlakuan disajikan pada Tabel 4 .

Hasil penelitian pada Tabel 4 dan 5, menunjukkan bahwa tingginya kandungan protein pada gelatin dari berbagai bahan baku kulit kaki ternak tidak selalu diikuti dengan tingkat viskositas yang tinggi. Sementara viskositas yang berkorelasi dengan tingkat kelembutan edible merupakan indikator yang baik dalam upaya produksi biopackaging pada produk pangan. Hasil penelitian pada tahap kedua ini menghasilkan rekomendasi pembuatan edible film berbasis gelatin dengan formula gelatin dan gliserol yakni 10 gr gelatin dan $1 \mathrm{~mL}$ gliserol dalam $100 \mathrm{~mL}$ aquades. Hal ini disebabkan karena pada kadungan protein yang tinggi tidak menghasilkan viskositas yang ideal. Pada rasio 10 : 1 menghasilkan hasil terbaik $(\mathrm{P}<0,05)$ dibandingkan yang lainnya.

\section{SIMPULAN}

Hasil penelitian dapat disimpulkan bahwa kualitas gelatin dari hidrolisis protein kolagen pada kulit sapi paling tinggi diikuti kulit kaki kambing dan kulit kaki ayam, baik dengan indikator protein maupun viskositas. Secara uji FTIR, produk ekstraksi kulit kaki ternak tersebut teridentifikasi sebagai gelatin melalui pengenalan gugus fungsi gelatin. Ketiga jenis bahan baku gelatin tersebut berpotensi dijadikan sebagai bahan baku edible film dengan formulasi gelatin $10 \mathrm{gr}$ dan gliserol $1 \mathrm{~mL}$ dalam $100 \mathrm{~mL}$ aquades.

\section{UCAPAN TERIMA KASIH}

Pada kesempatan ini tim peneliti mengucapkan banyak terima kasih kepada Dirjen Dikti dalam hal ini melalui Universitas Udayana dengan bantuan dana hibah Bersaing, sehingga kegiatan penelitian ini dapat berjalan dengan baik.

\section{DAFTAR PUSTAKA}

Caner, C., P.J. Vergano and J.L.Wiles. 1998. Chitosan film mechanical and permeation properties as affected by acid, plasticizer and storage. J. Food Sci, (63), 1049-1053.

Carvalho, R.A., P.J.A. Sobral, M. Thomazine, A.M.Q.B. Habitante, B. Giménez, M.C. Gómez-Guillén and P. Montero. 2007. Development of edible films based on differently processed Atlantic halibut (Hippoglossus hippoglossus) skin gelatin. Food Hydrocolloids, 22 (6), 1117-1123.

Kim, S.J dan Z. Ustunol. 2001. Thermal properties head seal ability and seal attributes of whey protein isolate lipid emulsion edible film. J.Food Sci, 66 (7), 985-990.

Krochta, J.M and M. Johnson. 1997. Edible and biodegradable polymer film : challenges and opportunities . J.Food Tech, (51), 61-74.

Krochta, J.M., E.A. Baldwin and M.O. Nisperos-Carriedo. 1994. Edible Coatings and Films to Improve Food Quality. Technomic Publishing Company, Inc. Pennsylvania, (2), 215-218.

Liu, Z and J.H. Han. 2005. Film forming characteristics of starckes. J. Food Sci, 70 (1), E.31-E36

Miwada, I N.S., dan I N. Simpen. 2005. Produksi dan Kualitas Gelatin dari Kulit Kaki Ayam Broiler dengan Metode Ekstraksi Termodifikasi. Laporan Penelitian Dosen Muda. Lembaga Penelitian. Universitas Udayana. Denpasar.

Purnomo, E. 1992. Penyamakan Kulit Kaki Ayam. Penerbit Kanisius. Yogyakarta.

Puspawati, N.M., I N. Simpen dan I N.S. Miwada. 2012. Isolasi gelatin dari kulit kaki ayam broiler dan karakterisasi gugus fungsinya dengan spetrofotometri FTIR. Jurnal Kimia 6(1): 79-87.

Sarkar, K.T. 1995. Theory and Practice of Leather Manufacture. Publ. The Author 4. Second Avenue Mahatma Gandhi Road. Madras.

Simelane, S and Z. Ustunol. 2005. Mechanical properties of heat cured whey protein based edible film compared with collagen casing under sausage manufacturing condition. J.Food Sci, 70 (2), E.131-134.

Sobral, P.J.A., F.C. Menegalli, M.D. Hubinger and M.A. Roques. 2001. Mechanical, water vapor barrier and thermal properties of gelatin based edible films. Food Hydrocolloids, (15), 423-432.

Steel, R.G.D and J.H.Torrie. 1991. Principle and Procedure of Statistics. $2^{\text {nd }}$.ed. International Book Company, Tokyo. 